\title{
Diagnostic value of Cobas Amplicor MTB and Rotorgene Real Time PCR for tuberculous meningitis: A six-year retrospective study
}

\author{
Gülnur Tarhan'1, Hülya Şimşek², Salih Cesur ${ }^{3}$ İsmail Ceyhan ${ }^{4}$ \\ ${ }^{1}$ Adryaman University, Faculty of Medicine, Department of Medical Microbiology, Adryaman, Turkey \\ ${ }^{2}$ National Public Health Institution, National Tuberculosis Reference Laboratory, Ankara, Turkey \\ ${ }^{3}$ Ankara Training and Research Hospital, Department of Infectious Diseases, Ankara, Turkey \\ ${ }^{4}$ Atatürk Chest Diseases and Thoracic Surgery Training and Research Hospital, Microbiology Laboratory, Ankara, Turkey
}

\begin{abstract}
Objective: Tuberculous meningitis (TBM) is the most severe and lethal form of tuberculosis (TB).Bacteriologic confirmation of TBM is difficult and slow. Therefore, most patients receive antituberculosis treatment based only on clinical and cerebrospinal fluid (CSF) characteristics. Rapid diagnosis of TBM is important to decrease morbidity and mortality. The aim of the study was to demonstrate that COBAS Amplicor MTB and Rotorgene Real Time (RT) PCR is a rapid method of diagnosing TBM before and after initiating anti-tuberculosis treatment.
\end{abstract}

Methods: A retrospective study was conducted between December 2002 and January 2009 in 468 patients with suspected TBM. Clinical specimens were collected from different hospitals in Ankara. All specimens were evaluated by smear microscopy and culture methods with Lowenstein-Jensen (LJ) and MGIT culture system.

Results: Using culture results as a gold standard, the sensitivity, specificity, positive predictive values (PPV), and negative predictive values (NPV) were $71.0 \%, 98.8 \%, 97.8 \%$ and $75.0 \%$, respectively, for COBAS Amplicor MTB and $80 \%, 98.9 \%$, $99.0 \%$ and $80.0 \%$, respectively, for Rotorgene RT PCR. Statistical analysis showed no significant differences between the COBAS Amplicor MTB and Rotorgene RT PCR ( $p \geq 0.05)$. All isolates were susceptible to isoniazid, rifampin, streptomycin, and ethambutol with proportion method in LJ medium. All isolates were defined as LAM7-TUR by spoligotyping.

Conclusion: Retrospective analysis of COBAS Amplicor MTB and Rotorgene RT PCR found that both tests are effective in rapidly diagnosing MTB using CSF. It was concluded that Rotorgene RT PCR test is more sensitive (81.0\%) than COBAS Amplicor MTB (71.0\%). J Microbiol Infect Dis 2015;5(4): 156-161

Key words: Tuberculous meningitis, COBAS Amplicor MTB, Rotorgene Real Time PCR

\section{Tüberküloz menenjiti için Cobas Amplicor MTB ve Rotorgene Real Time PCR'ın tanı değeri: 6 yıllık retrospektif çalışma}

\section{ÖZET}

Amaç: Tüberküloz menejiti (TBM), tüberkülozun (TB) en şiddetli ve öldürücü formudur. TBM'nin bakteriyolojik tanısı zor ve zaman alıııdır. Bu nedenle, hastaların çoğu sadece klinik ve beyin omurilik sıvısı (BOS)'nın özelliklerine göre anitüberküloz tedavisine alınmaktadır. TBM'nin hızlı tanısı ölüm ve hastalık oranlarını azaltılmasına önem taşımaktadır. Bu çalışmanın amacı tedavi öncesinde ve tedaviye başladıktan sonra TBM'nin tanımlanmasında hızlı bir yöntem olarak COBAS Amplicor MTB ve Rotorgene Real Time PCR (RT PCR)'ın etkinliğinin araştııılmasıdır.

Yöntemler: Bu retrospektif çalışma Ekim 2002-Ocak 2009 tarihleri arasında tüberküloz şüpheli 468 adet BOS örneği ile yapıldı. Klinik örnekler Ankara'daki çeşitli hastanelerden toplandı. Bütün örnekler yayma mikroskopi, katı (Lowenstein-Jensen) ve sIVI besiyerinde (MGIT 960 kültür sistemi) kültür, COBAS Amplicor MTB ve Rotorgene RT PCR yöntemleri ile değerlendirildi.

Bulgular: Kültür yöntemi altın standart olarak kabul edildiğinde duyarlıık, özgüllük, pozitif belirleyicilik değeri (PBD) ve negatif belirleyicilik değeri (NBD) sırası ile COBAS Amplicor MTB için \%71,0, \%98,8, \%97,8 ve \%75,0; Rotorgene RT PCR için \%80,0, \%98,9, \%99,0 ve \%80,0 olarak bulundu. İstatistiksel analizlerde COBAS Amplicor MTB ve Rotorgene RT PCR testi arasına anlamlı bir fark bulunmadı $(p \geq 0.05)$. Löwenstein Jensen besiyerinde proporsiyon yöntemine gore yapılan 
ilaç duyarlılık testlerinde bütün izolatlar izoniazid, rifampin, streptomisin ve etambutol'a hassas olarak saptandı. Bütün izolatlar spoligotiplendirme yöntemi ile LAM7-TUR olarak tanımlandı.

Sonuç: Altı yılık retospektif değerlendirmede COBAS Amplicor MTB ve Rotorgene RT PCR testleri BOS örneklerinden MTB'nin hızlı tanısında etkin bulundu. Rotorgene RT-PCR testinin $(\% 81,0)$, COBAS Amplicor MTB $(\% 71,0)$ testinden daha duyarlı bulundu.

Anahtar kelimeler: Tüberküloz menenjiti, COBAS Amplicor MTB, Rotorgene Real Time PCR

\section{INTRODUCTION}

Tuberculous meningitis (TBM) caused by M. tuberculosis is the most common form of Central Nervous System (CNS) tuberculosis (TB); the condition has very high rates of morbidity and mortality. ${ }^{1,2}$ TBM accounts for approximately $1 \%$ of total TB cases in the United States and causes death and severe neurological defects in more than half of those affected. The onset of TBM is insidious in children younger than 5 years of age, school-age children, and adolescents. ${ }^{3}$ Death from TBM occurs due to delays in diagnosis and treatment. ${ }^{3}$

Definitive diagnosis of TBM requires detection of $\mathrm{M}$. tuberculosis bacilli in CSF. Although culture technique is considered the "gold standard", it has limitation in rapid diagnosis due to late growth and to the length of time required to arrive at a clinical diagnosis. ${ }^{4}$ Microscopy is fast, but its sensitivity is variable $(20 \%-80 \%) .{ }^{5}$ For this reason, microscopy can be used as rapid and accurate diagnostic methods for TBM. Molecular techniques are thought to be promising approaches for the diagnosis of TBM due to their efficiency, sensitivity and specificity. ${ }^{4}$ From nucleic acid amplification techniques, real time PCR used in the diagnosis of TBM has a short turn-around time. ${ }^{6-8}$ The COBAS Amplicor M. tuberculosis (MTB) PCR test (Roche Diagnostic Systems, Inc., Branchburg, NJ, USA) is an automated standardized commercial test used for the detection of MTB, based on the amplification of nucleic acids. ${ }^{9}$ The COBAS Amplicor MTB PCR test is a rapid and highly specific diagnostic test for TBM. ${ }^{10}$ The GenProbe Amplified M. tuberculosis Direct Test (MTD) for detecting MTB complex in CSF is also thought to be efficient, sensitive, and specific. ${ }^{11}$

The COBAS Amplicor MTB PCR and Rotorgene RT PCR tests are techniques commonly used to detect MTB using clinical samples. The COBAS Amplicor MTB PCR is validated for respiratory specimens, but many physicians also request PCR analyses for non-respiratory specimens. For this reason, we conducted a retrospective study to determine whether the COBAS Amplicor MTB PCR test and Rotorgene RT PCR can be used to rapid diagnose TBM before and after initiation of anti-tuberculosis treatment.

\section{METHODS}

A 6-year retrospective study was conducted between December 2002- January 2009 in 468 patients with suspected TBM in Refik Saydam Hygiene Center, National Tuberculosis Reference Laboratory, Ankara. The ages of the 468 patients ranged from 11 to 76 years, with a mean age of 39.3 years. One hundred and fifty three of 468 CSF samples were obtained from female, and 315 obtained from male. Clinical specimens were collected from different hospitals in Ankara.

All specimens were processed by conventional procedures for sterile specimens. For each specimen, smear microscopy was done and stained with the Ziehl Neelsen (ZN) method. The number of acid-fast bacilli seen in the whole slide was recorded. Five hundred microliters of each specimen was inoculated in BACTEC Mycobacteria Growth Indicator Tube (MGIT) 960 liquid medium (Becton Dickinson, USA) and $150 \mu \mathrm{l}$ was inoculated onto Lowenstein-Jensen (LJ) slants. Slants were incubated at $37^{\circ} \mathrm{C}$ for about 8 weeks. LJ slants were evaluated for growth on a weekly basis, whereas the BACTEC MGIT 960 system provided continuous monitoring. Presumed mycobacterial growth was confirmed by ZN staining. ${ }^{12}$ If no growth was observed after 8 weeks of incubation, the specimen was reported as culture negative. Culture-positive specimens were evaluated by spoligotyping for molecular typing. Drug susceptibility testing to rifampicin (R), isoniazid (I), streptomycin (S), and ethambutol (E) was performed by using standard proportion method on LJ medium. ${ }^{12,13}$

COBAS Amplicor MTB (Roche Molecular Systems, Inc., Branchburg, NJ.) and Rotorgene Real Time PCR (Rotor-Gene $®$ Q, Germany) and Artus $®$ Real Time PCR Kits, were studied in accordance with the manufacturer's instructions. (Rotor-Gene $\AA$ $\mathrm{Q}$ and artus ${ }^{\circledR}$ PCR Kits-Pure Pathogen Detection2010-Available from: www.qiagen.com). ${ }^{14}$ 
Culture-positive specimens for molecular typing were evaluated by spoligotyping method. ${ }^{15}$ Spoligotyping was carried out with a commercial kit (Isogen Bioscience BV, Maarssen, the Netherlands) according to the manufacturer's instructions. ${ }^{11}$ The 43 spacers between the direct repeats in the target region were amplified by using DRa biotinylated at the 59 end and DRb primers. The PCR product was hybridized to a membrane containing 43 oligonucleotides derived from the spacer sequences of $\mathrm{M}$. tuberculosis H37Rv and M. bovis BCG P3 by reverse line blotting. M. tuberculosis H37Rv and $M$. bovis BCG P3 were used as controls for spoligotyping. Spoligotypes results were converted into octal code and in the SITVIT2 proprietary database at the Pasteur Institute of Guadeloupe, which is an updated version of the previously released SpoIDB4 database (available at http://www.pasteurguadeloupe. fr:8081/SITVITDemo).

\section{Statistical Analysis}

The sensitivity, specificity, positive predictive value (PPV), and negative predictive value (NPV) of the nine NAATs were calculated by using culture results as the reference standards. Statistical comparisons of the nine methods were performed by using the chi-square test; a $P$ value of $<0.05$ was considered significant. The analysis was performed by using of SPSS, version 14.0 (SPSS).

\section{RESULTS}

The positivity rates of microscopy, culture and PCR tests (COBAS Amplicor MTB and Rotorgene RT PCR test) are shown in Figure 1.

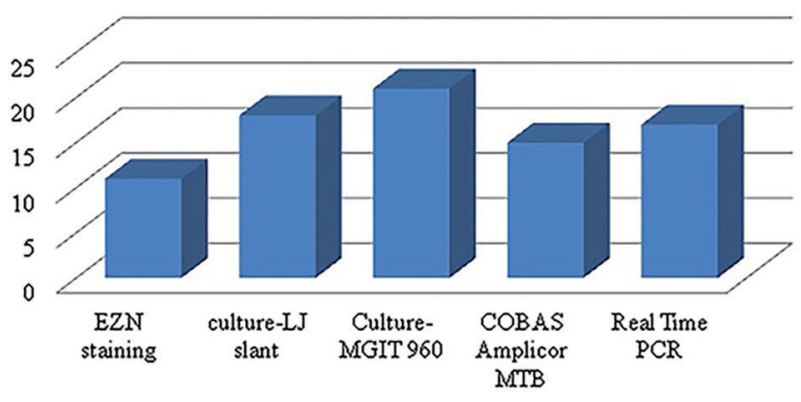

Figure 1. Positivity rates of microscopy, culture and PCR tests.

Using MGIT 960 culture results as a gold standard, the sensitivity, specificity, positive (PPV) and negative predictive values (NPV) of the COBAS Amplicor MTB and Rotorgene RT PCR were $71 \%$, $98.8 \%, 75 \%$ and $98.6 \%$, respectively, for COBAS
Amplicor MTB and $81 \%, 98.8 \%, 77 \%$ and $99 \%$, respectively, for Rotorgene RT PCR (Figure 2, Figure $3)$.

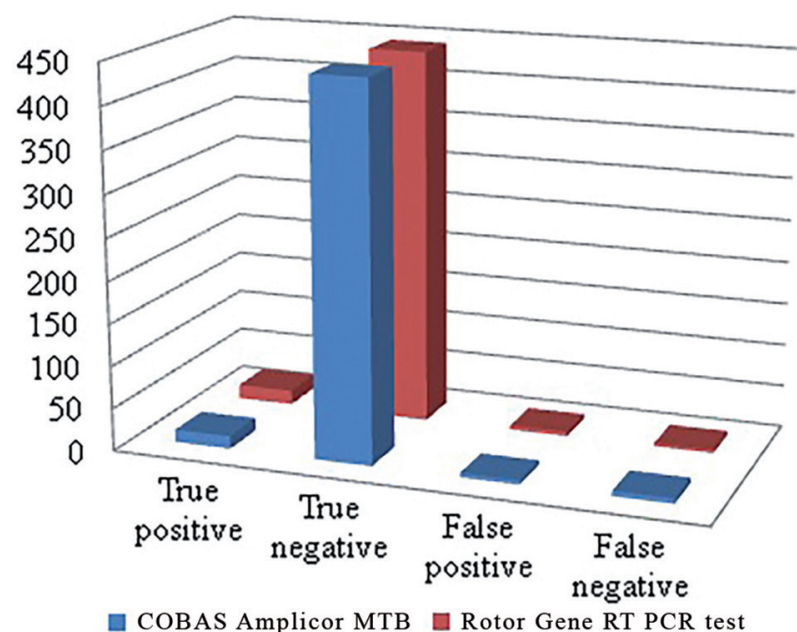

Figure 2. Results of PCR in Cerebrospinal Fluid.

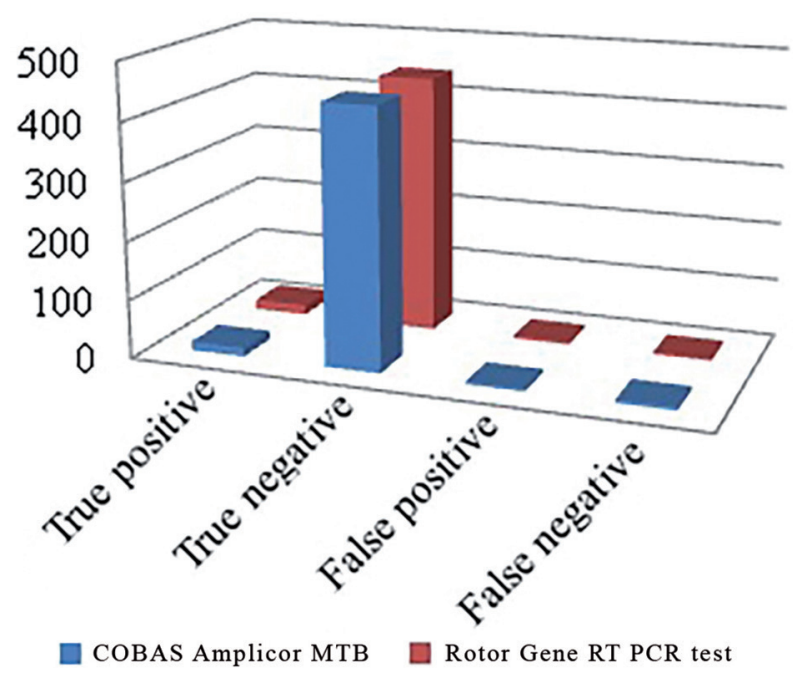

Figure 3. Sensitivity, specificity, positive predictive value and negative predictive value of 468 samples.

All isolates were found to be susceptible to isoniazid, rifampin, streptomycin, and ethambutol. In this study, all isolates were defined LAM7-TUR as a common MTB type (Table 1).

Table 1. MTB types of isolates defined by spoligotyping method

\begin{tabular}{llll}
\hline \multicolumn{2}{l}{ Results of Spoligotyping } & & Pattern Code \\
Octal Number & SIT & Family & \\
\hline 777737404760771 & 41 & LAM7-TUR & 7 \\
777737404760771 & 41 & LAM7-TUR & 2 \\
\hline
\end{tabular}




\section{DISCUSSION}

Rapid diagnosis of TBM is highly important to decrease morbidity and mortality. TBM is still a complex issue because of inconsistent clinical presentations and a lack of a rapid, sensitive, and specific test. Various nucleic acid-based amplification tests are available for the detection of MTB, but few data are available on their use to diagnose TBM. The COBAS Amplicor MTB and Rotorgene RT PCR are useful for the rapid diagnosis of MTB using CSF.

Erdem et al. ${ }^{16}$ analysed 506 TBM cases with microbiologically confirmed in the Haydarpasa-I study. They reported that the sensitivities of the tests were $90.2 \%$ for interferon-gama release assay (Quantiferon TB gold in tube ${ }^{\circledR}$ ), $81.8 \%$ for automated culture systems (AMC), 72.7\% for Lowenstein-Jensen medium (L-J), $29.9 \%$ for adenosine deaminase (ADA), and 27.3 for Ehrlich-Ziehl-Neelsen staining (EZNs), respectively. In this study it is reported that cerebrospinal fluid (CSF) -ACS was superior to CSF L-J culture and CSF-PCR with statistically significant. As a results, CSF-L-J culture was superior to CSF-PCR in this study. In addiyion to this result, they reported that fair and inverse agreement was detected for CSF-ADA and CSF-PCR. They concluded that diagnostic accuracy of TBM was increases when both ACS and L-J solid cultures were used together and non-culture tests such as CSFPCR, CSF-ADA and EZNs tests contributed TBM diagnosis with different ratios. Consequntly, they stated that the diagnostic approach to TBM can be individualized according to the technical capacity of each institions.

In our study, we used both COBAS Amplicor MTB and Rotorgene RT PCR tests to detect MTB from CSF samples. According to the our results, 20 of 468 CSF samples were found positive by COBAS Amplicor MTB, while 22 were positive by Rotorgene RT PCR method. 448 samples were negative by COBAS Amplicor MTB, while 446 were negative by Rotorgene RT PCR. In comparison with culture as the reference method, 5 false-positive results and 6 false-negative results were detected by COBAS Amplicor MTB assay, while 5 false-positive results and 4 false-negative results were found by Rotorgene RT PCR. The sensitivity, specificity, PPV and NPV were $71 \%, 98.8 \%, 97.8 \%$ and $75 \%$, respectively, for COBAS Amplicor MTB and $80 \%, 98.9 \%, 99 \%$ and $80 \%$, respectively for Rotorgene RT PCR. Statistical analysis showed that there were no significant differences among the nine NAATs $(p \geq 0.05)$. Our study results were not consistent with the results of the Erdem et al. This situation may be due to the different PCR methods (such as Probe Tec $®$ and Gen Expert@) used in our study and Erdem et al. ${ }^{16}$

Wei and coworkers17 used the nested PCR assays developed previously to detect and identify MTB from CSF samples of patients with suspected TBM and non-tuberculous patients in their study. ${ }^{16}$ From 11 CSF samples analyzed, 5 samples were from patients with suspected TBM and 6 samples were from the clinically diagnosed non-tuberculous patients. Surprisingly, two of the non-tuberculous patients were shown as MTB positive. This finding supported that nested PCR was an important test for the diagnosis of TBM.

In the study performed by Reischl and coworkers ${ }^{18}$, COBAS Amplicor PCR was used to detect MTB in respiratory and nonrespiratory clinical specimens sent to their laboratory for routine MTB testing. ${ }^{17}$ Of the 77 CSF samples collected, 3 samples were PCR positive, 74 samples were PCR negative, one sample was false positive, and one sample was false negative, in comparison with culture as the reference method. The authors stated that the number of false negatives could be further reduced by raising the portion of the original sediment introduced to PCR testing.

A study has been conducted in 2000 patients to assess the role of COBAS Amplicor PCR test in the early diagnosis of TBM. ${ }^{10}$ Eighty-three CSF samples were collected prospectively from 69 patients with suspected TBM. In this study, it was concluded that the COBAS Amplicor TB PCR test was a rapid and highly specific diagnostic test for TBM.

Thwaites et al. ${ }^{19}$ and coworkers compared their performance by ZN staining, Gen-Probe amplified MTD test, and culture from 341 CSF specimens. They found that sensitivity, specificity, and PPV and NPV for MTD were $38 \%, 99 \%, 96 \%$, and $66 \%$, respectively. MTD was more sensitive than ZN staining. However, it appeared that the sensitivities of $Z N$ staining, MTD, and the two tests combined were improved to $64 \%, 59 \%$, and $83 \%$, respectively, when repeated sampling. They concluded that ZN staining of the CSF is at least as good as MTD for the rapid diagnosis of TB, but the combination of these methods on serial samples detected more cases.

In Chedore and Jamieson's 5-year retrospective study, the utility of MTD in detecting MTB complex was evaluated. ${ }^{20}$ From 311 CSF samples, 17 were positive. When compared with culture as the gold standard, the sensitivity and specificity of the MTD test were $93.8 \%$ and $99.3 \%$, respectively. PPV 
and NPV for TBM were $88.2 \%$, and $99.7 \%$. The study found that MTD test was rapid, sensitive, and specific for TBM. These results were corroborated with our results.

Pai and coworkers ${ }^{21}$ did a systematic review and meta-analysis to establish the diagnostic accuracy of nucleic acid amplification (NAA) tests for TBM from 49 studies. The summary estimates in 14 studies with commercial NAA tests were sensitivity $0.56(95 \% \mathrm{Cl} 0.46,0.66)$, specificity 0.98 (0.97, 0.99), positive likelihood ratio 35.1 (19.0, 64.6), negative likelihood ratio $0.44(0.33,0.60)$, and diagnostic odds ratio $96.4(42.8,217.3)$. It was thought that the summary accuracy could not be established with confidence because of wide variability in test accuracy in the 35 studies with in-house ("home-brew") tests. It was stated that commercial NAA tests showed a potential role in confirming TBM diagnosis, although their overall low sensitivity precluded the use of these tests to rule out TBM with certainty. This meta analysis provided valuable information that helped us arrive at the conclusion of our study.

The limitations of our study were the lack of some epidemiological, clinic, and laboratory dataes of all TBM. Therefore, a detailed analysis could not be performed based on clinical data. In our study, all culture-positive samples isolates were detected as LAM 7 TUR by spoligotyping for molecular epidemiologic evaluation. Our data were consistent with the findings from studies conducted in the different geographical regions of our country. ${ }^{15,22-24}$

We concluded that COBAS Amplicor MTB and Rotorgene RT PCR tests are effective for the rapid diagnosis of TBM using CSF. We thought that Rotorgene RT PCR test was better than COBAS Amplicor MTB, and also DNA extraction was the most important step for test performance.

Acknowledgement: This study has been presented as a poster at the 34thAnnual Congress of the European Society of Mycobacteriology, P197,Florence Italy,30 June -03 July, 2013.

\section{REFERENCES}

1. Marx GE, Chan ED. Tuberculous meningitis: diagnosis and treatment overview. Tuberc Res Treat 2011; 2011:798764.

2. Rock RB, Olin M, Baker CA, et al. Central nervous system tuberculosis: pathogenesis and clinical aspects. Clin Microbiol Rev 2008;21:243-261.

3. Thwaites G, Chau TTH, Mai NTH, et al. Tuberculosis meningitis. J. Neurol Neurosurg Psychiatry 2000;68:289-299.

4. Takahashi T, Tamura M, Takasu T. The PCR-Based Diagnosis of Central Nervous System Tuberculosis: Up to Date Tuber- culosis Research and Treatment 2012; Volume 2012, Article ID 831292, 17 pages http://dx.doi.org/10.1155/2012/831292

5. Swarnlata P, Shoba K and Khublani TK. A review on TB and its advance diagnostic techniques. International Journal of Pharma and Bio Sciences 2011;2:535-545.

6. Young CS, Kim MJ, Suh JT, Lee HJ. Comparison of Diagnostic Performance of Three Real-Time PCR Kits for Detecting Mycobacterium Species. Yonsei Med J 2011;52:301-306.

7. D'amato RF, Wallman AA, Hochstein LH, et al. Rapid diagnosis of pulmonary tuberculosis by using Roche AMPLICOR Mycobacterium tuberculosis PCR test. J Clin Microbiol 1995;33:1832-1834.

8. Ninet B, Rohner P, Metral C, Auckenthaler R. Assessment of use of the COBAS AMPLICOR system with BACTEC 12B cultures for rapid detection of frequently identified mycobacteria. J Clin Microbiol 1999;37:782-784.

9. Kim TK, Mukhopadhyay A, Gough A, Khoo K-L, et al. Role of clinical judgment in the application of a nucleic acid amplification test for the rapid diagnosis of pulmonary tuberculosis. Chest 2003; 124:902-908.

10. Bonington A, Strang JI, Klapper PE, et al. TB PCR in the early diagnosis of tuberculous meningitis: evaluation of the Roche semi-automated COBAS Amplicor MTB test with reference to the manual Amplicor MTB PCR test. 2000;80:191-196.

11. Chedore P, Jamieson FB. Rapid molecular diagnosis of tuberculous meningitis using the Gen-probe Amplified Mycobacterium Tuberculosis direct test in a large Canadian public health Laboratory. Int J Tuberc Lung Dis 2002;6:913-919.

12. Kent PT, Kubica G. Public Health Mycobacteriology. A guide for the level III Laboratory. Atlanta, Ga: Centers for Disease Control, 1985.

13. Canetti G, Fox W, Khomenko A, et al. Advances in techniques of testing mycobacterial drug sensitivity, and the use of sensitivity tests in tuberculosis control programmes. Bull World Health Organisation 1969;41:21-43.

14. Jungkind D, DiRenzo S, Beavis KG, Silverman NS. Evaluation of automated COBAS AMPLICOR PCR system for detection of several infectious agents and its impact on laboratory management. J Clin Microbiol 1996;34:2778-2783.

15. Kısa O, Tarhan,G, Gunal S, et al. The Distribution of Spoligotyping Defined Genotypic Lineages Among Drug-Resistant M. tuberculosis complex Clinical Isolates in Ankara, Turkey. Plos One 2012;7:e30331.

16. Erdem $\mathrm{H}$, Engin DO, Elaldi $\mathrm{N}$, et al. The microbiological diagnosis of tuberculous meningitis : results of Haydarpasa-I study. Clinical Microbiology and Infection 2014;20:0600-8. doi: 10.1111469-0691.

17. Wei CY, Hwang JJ, Chu CH, Lee CP.Detection and identification of Mycobacterium tuberculosis by nested PCR assays in cerebrospinal fluid samples from patients with suspected tuberculous meningitis. Kaohsiung J Med Sci 1999;15:475483.

18. Reischl U, Lehn N, Wolf H, Naumann L. Clinical Evaluation of the Automated COBAS AMPLICOR MTB Assay for Testing Respiratory and Nonrespiratory Specimens. J Clin Microbiol 1998;36:2853-2860.

19. Thwaites GE, Caws M, Chau TT, et al. Comparison of conventional bacteriology with nucleic acid amplification (amplified mycobacterium direct test) for diagnosis of tuberculous meningitis before and after inception of antituberculosis chemotherapy. J Clin Microbiol 2004;42:996-1002.

20. Chedore $P$, Jamieson FB. Rapid molecular diagnosis of tuberculous meningitis using the Gen-probe Amplified Myco- 
bacterium Tuberculosis direct test in a large Canadian public health laboratory. Int J Tuberc Lung Dis 2002;6:913-919.

21. Pai M, Flores LL, Pai N, et al. Diagnostic accuracy of nucleic acid amplification tests for tuberculous meningitis: a systematic review and meta-analysis. Lancet Infect Dis 2003;3:633-643.

22. Kisa O, Albay A, Baylan O, et al. Genetic diversity of Mycobacterium tuberculosis isolates at the Military Medical Academy in Ankara, Turkey. Res 2007; Microbiol 158:318-323.
23. Otlu B, Durmaz R, Gunal S, et al. Beijing/W and majör spoligotype families of Mycobacterium tuberculosis strains isolated from tuberculosis patients in Eastern Turkey. New Microbiol 2009;32:255-263.

24. Zozio T, Allix C, Gunal S, et al. Genotyping ofMycobacterium tuberculosis clinical isolates in two cities of Turkey: Description of a new family of genotypes that is phylogeographically specific for Asia Minor. BMC Microbiology 2005;5:44. 